\title{
Supramolecular hydrogen-bonded structure of a 1:2 adduct of melamine with boric acid
}

\author{
Abhijit Roy ${ }^{\mathrm{a}}$, Amitava Choudhury ${ }^{\mathrm{a}, \mathrm{b}}$, C.N.R. Rao ${ }^{\mathrm{a}, \mathrm{b}, *}$ \\ ${ }^{a}$ Chemistry and Physics of Materials Unit, Jawaharlal Nehru Centre for Advanced Scientific Research, Jakkur PO, Bangalore 560 064, India \\ ${ }^{\mathrm{b}}$ Solid State and Structural Chemistry Unit, Indian Institute of Science, Bangalore 560 012, India
}

Received 24 January 2002; revised 28 February 2002; accepted 28 February 2002

\begin{abstract}
Boric acid (B) forms a 2:1 hydrogen-bond adduct, M-2B, with melamine (M), wherein, a finite tetrameric ribbon of boric acid forms hydrogen bonds with the nitrogen donor sites of $\mathrm{M}$. Hydrogen-bonded layers of $\mathrm{B}$ and $\mathrm{M}$ in the $b c$-plane are connected by boric acid units along the $a$-axis to give a three dimensional structure. Interestingly, one of the amino groups of $\mathrm{M}$ does not participate in hydrogen bonding unlike all the hydroxyl groups of B. (C) 2002 Elsevier Science B.V. All rights reserved.
\end{abstract}

Keywords: Boric acid; Melamine; Hydrogen bonding; Supramolecular chemistry; Hydrothermal synthesis

\section{Introduction}

Boric acid, $\mathrm{B}(\mathrm{OH})_{3}$, would be expected to be a good building block for supramolecular hydrogen bonded structures by virtue of the presence of three $\mathrm{OH}$ groups oriented in a planar triangular fashion. Boric acid is known to behave as a lewis acid with the formation of the tetrahedral anion $\left[\mathrm{B}(\mathrm{OH})_{4}\right]^{-}$rather than as a Brønsted acid with the formation of the conjugate base anion $\left[\mathrm{BO}(\mathrm{OH})_{2}\right]^{-}$. In dilute aqua solution $\mathrm{B}(\mathrm{OH})_{3}$ exist as an equilibrated mixture of the undissociated acid and $\left[\mathrm{B}(\mathrm{OH})_{4}\right]^{-}$anion. At higher concentrations monomeric borate species undergo condensation to give a variety of oligomeric hydroxo (oxo) borate anions [1]. Accordingly, several

\footnotetext{
* Corresponding author. Address: Chemistry and Physics of Materials Unit, Jawaharlal Nehru Centre for Advanced Scientific Research, Jakkur PO, Bangalore 560 064, India. Tel.: +91-80-8462762; fax: +91-80-846-2766.

E-mail address: cnrrao@jncasr.ac.in (C.N.R. Rao).
}

interesting supramolecular hydrogen-bonded architectures involving tetrahydroxy pentaborate and boric acid incorporating a tertiary or quarternary ammonium ion have been isolated and characterized [2-5]. Hydrogen-bonded structures involving only monomeric borate species is, however rare. In $\left(\mathrm{CH}_{3}\right)_{4}$ $\mathrm{N}^{+}\left(\mathrm{BO}(\mathrm{OH})_{2}\right)^{-} \cdot 2\left(\mathrm{NH}_{2}\right)_{2} \mathrm{CO} \cdot \mathrm{H}_{2} \mathrm{O}$ and $\left(\mathrm{NEt}_{4}\right)_{2}[-$ $\left.\mathrm{BO}(\mathrm{OH})_{2}\right]_{2} \cdot \mathrm{B}(\mathrm{OH})_{3} \cdot 5 \mathrm{H}_{2} \mathrm{O},\left[\mathrm{BO}(\mathrm{OH})_{2}\right]^{-}$is present in the host lattice $[6,7] .\left[\left(\mathrm{PPh}_{3}\right)_{2} \mathrm{~N}^{+} \cdot \mathrm{Cl}^{-}\right] \cdot \mathrm{B}(\mathrm{OH})_{3}$ and $\left[\left(\mathrm{C}_{2} \mathrm{H}_{5}\right)_{4} \mathrm{~N}^{+}\right]_{2} \mathrm{CO}_{3}^{2-} \cdot\left(\mathrm{NH}_{2}\right)_{2} \mathrm{CO} \cdot 2 \mathrm{~B}(\mathrm{OH})_{3} \cdot \mathrm{H}_{2} \mathrm{O}$ seems to be the only two structures known to date containing the undissociated $\mathrm{B}(\mathrm{OH})_{3}$ unit $[7,8]$. We wanted to study supramolecular hydrogen-bonded assemblies formed by boric acid with organic amines and such compounds (Scheme 1) under aqueous conditions. We have found that melamine (M) which is well known to yield excellent hydrogen-bonded structures also forms a stable 1:2 adduct with boric acid (M-2B). Importantly, this adduct is a precursor for making $\mathrm{BN}$ nanotubes [9-11]. We have carried out a study of 
<smiles>Nc1nc(N)nc(NI)n1</smiles>

Melamine (M)<smiles>OB(O)O</smiles>

Boric Acid (B)

Scheme 1.

$\mathrm{M} \cdot 2 \mathrm{~B}$ prepared by the hydrothermal technique, to examine the features of this supramolecularly hydrogen-bonded structure.

\section{Experimental}

$0.1295 \mathrm{~g}$ of $\mathrm{H}_{3} \mathrm{BO}_{3}$ was dissolved in $2 \mathrm{ml}$ distilled water. To this solution, $0.1317 \mathrm{~g}$ of melamine was added with stirring. The stirring was continued for another $30 \mathrm{~min}$ to get a homogenous solution. The reaction mixture with a composition of $2 \mathrm{H}_{3} \mathrm{BO}_{3} /$ melamine $/ 100 \mathrm{H}_{2} \mathrm{O}$ was then sealed in a $23 \mathrm{ml}$ capacity teflon-lined stainless steel autoclave and heated at $150{ }^{\circ} \mathrm{C}$ for $2 \mathrm{~d}$. It was subjected to natural cooling $(\sim 4 \mathrm{~h})$. The product containing rod-shaped crystals suitable for single crystal X-ray diffraction was filtered and washed with chilled de-ionized water. The initial $\mathrm{pH}$ of the mixture was seven and there was no appreciable change in the $\mathrm{pH}$ of the supernatant in the final mixture. Heating the reaction mixture for a longer time $(3 \mathrm{~d})$ makes the supernatant highly alkaline $(\mathrm{pH} \sim 10.5)$, probably due to the evolution of the ammonia gas which is produced due to the decomposition of melamine under hydrothermal condition as indicated by the smell of ammonia upon opening the autoclave. The product was subsequently characterized by powder Xray diffraction (PXRD), single crystal X-ray diffraction, thermogravimetric analysis (TGA) and IR spectroscopy. The PXRD immediately revealed that the product is a 1:2 (M.2B) adduct of melamine and boric acid [9]. Our attempts to synthesize 1:1 adduct under similar condition led to recrystallization of melamine. On the other hand attempts to synthesize a composition of 1:3 under similar condition gives back the 1:2 adduct of melamine and boric acid.

A suitable single crystal of $\mathrm{M} \cdot 2 \mathrm{~B}$ was carefully
Table 1

Crystal data and structural refinement parameters for M.2B

\begin{tabular}{|c|c|}
\hline Empirical formula & $\mathrm{C}_{3} \mathrm{H}_{12} \mathrm{~B}_{2} \mathrm{~N}_{6} \mathrm{O}_{6}$ \\
\hline Crystal system & Monoclinic \\
\hline Space group & $P 2{ }_{1} / c$ \\
\hline Crystal size (mm) & $0.33 \times 0.10 \times 0.08$ \\
\hline$a(\AA)$ & $3.6015(2)$ \\
\hline$b(\AA)$ & $20.1400(13)$ \\
\hline$c(\AA)$ & $14.1279(9)$ \\
\hline$\alpha\left(^{\circ}\right)$ & 90.0 \\
\hline$\beta\left(^{\circ}\right)$ & $92.134(2)$ \\
\hline$\gamma\left({ }^{\circ}\right)$ & 90.0 \\
\hline Volume $\left(\AA^{3}\right)$ & $1024.05(11)$ \\
\hline$Z$ & 4 \\
\hline Formula mass & 249.81 \\
\hline$\rho\left(\mathrm{g} \mathrm{cm}^{-3}\right)$ & 1.620 \\
\hline$\lambda(\mathrm{Mo} \mathrm{K} \alpha)(\AA)$ & 0.71073 \\
\hline$\mu\left(\mathrm{mm}^{-1}\right)$ & 0.144 \\
\hline $\begin{array}{l}\text { Temperature of } \\
\text { measurement }(\mathrm{K})\end{array}$ & $293(2)$ \\
\hline$\theta$ range $\left({ }^{\circ}\right)$ & $1.76-23.32$ \\
\hline Total data collected & 4170 \\
\hline Index ranges & $\begin{array}{l}-3 \leq h \leq 3 \\
-20 \leq k \leq 22 \\
-11 \leq l \leq 15\end{array}$ \\
\hline Unique data & 1446 \\
\hline Observed data $[I>2 \sigma(I)]$ & 923 \\
\hline$R_{\text {int }}$ & 0.0529 \\
\hline Refinement method & Full-matrix least-squares on $F^{2}$ \\
\hline$R$ indices $[I>2 \sigma(I)]$ & $R_{1}=0.0490, w R_{2}=0.1014^{\mathrm{a}}$ \\
\hline$R$ (all data) & $R_{1}=0.0910, w R_{2}=0.1214$ \\
\hline Goodness of fit $(S)$ & 1.004 \\
\hline Number of variables & 202 \\
\hline $\begin{array}{l}\text { Largest difference map peak } \\
\text { and hole e } \AA^{-3}\end{array}$ & 0.186 and -0.286 \\
\hline
\end{tabular}

selected under a polarizing microscope and glued to a thin glass fiber with cyanoacrylate (super glue) adhesive. Single crystal structure determination by X-ray diffraction was performed with a Siemens Smart-CCD diffractometer equipped with a normal focus, $2.4 \mathrm{~kW}$ sealed tube X-ray source (Mo K $\alpha$ radiation, $\lambda=0.71073 \AA$ ) operating at $50 \mathrm{kV}$ and $40 \mathrm{~mA}$. A hemisphere of intensity data were collected using SMART software [12] at room temperature in 1321 frames with $\omega$ scans (width of $0.30^{\circ}$ and exposure time of $20 \mathrm{~s}$ per frame) in the $2 \theta$ range $3-$ $46.5^{\circ}$. The total collected data were reduced using SAINT [12] program and the orientation matrix along with the detector and the cell parameters were refined 
Table 2

Atomic coordinates $\left(\times 10^{4}\right)$ and equivalent isotropic displacement parameters $\left(\AA^{2} \times 10^{3}\right)$ for, M.2B

\begin{tabular}{|c|c|c|c|c|}
\hline Atom & $x$ & $y$ & $z$ & $U(\mathrm{eq})^{\mathrm{a}}$ \\
\hline $\mathrm{B}(1)$ & 4507 (11) & 3673 (2) & $1673(3)$ & $32(1)$ \\
\hline $\mathrm{B}(2)$ & $3380(11)$ & $4891(2)$ & $6371(3)$ & $35(1)$ \\
\hline $\mathrm{O}(1)$ & 3264 (7) & $3640(1)$ & $2576(2)$ & $37(1)$ \\
\hline $\mathrm{O}(2)$ & $5998(7)$ & $4253(1)$ & $1348(2)$ & $40(1)$ \\
\hline $\mathrm{O}(3)$ & $4251(7)$ & 3137 (1) & $1102(2)$ & $41(1)$ \\
\hline $\mathrm{O}(4)$ & $2641(7)$ & 4377 (1) & $5776(2)$ & $48(1)$ \\
\hline $\mathrm{O}(5)$ & $2512(7)$ & $4852(1)$ & 7295 (2) & $43(1)$ \\
\hline $\mathrm{O}(6)$ & $5003(7)$ & $5459(1)$ & $6045(2)$ & $44(1)$ \\
\hline $\mathrm{C}(1)$ & 8379 (8) & $3726(2)$ & $-1110(2)$ & $29(1)$ \\
\hline $\mathrm{N}(1)$ & $9621(7)$ & $3728(1)$ & $-1992(2)$ & $29(1)$ \\
\hline $\mathrm{C}(2)$ & $10305(9)$ & 3125 (2) & $-2354(2)$ & $29(1)$ \\
\hline $\mathrm{N}(2)$ & 9997 (7) & $2546(1)$ & $-1885(2)$ & $30(1)$ \\
\hline $\mathrm{C}(3)$ & $8648(8)$ & $2606(2)$ & $-1020(2)$ & $30(1)$ \\
\hline $\mathrm{N}(3)$ & 7729 (7) & $3174(1)$ & $-595(2)$ & $30(1)$ \\
\hline $\mathrm{N}(4)$ & 7727 (9) & 4309 (2) & $-695(2)$ & $41(1)$ \\
\hline $\mathrm{N}(5)$ & $11429(9)$ & 3098 (2) & $-3245(2)$ & 38 (1) \\
\hline $\mathrm{N}(6)$ & $8262(9)$ & 2043 (2) & $-514(3)$ & $43(1)$ \\
\hline $\mathrm{H}(1)$ & $7323(93)$ & 4299 (17) & $-54(26)$ & $52(11)$ \\
\hline $\mathrm{H}(2)$ & 7977 (105) & $4696(22)$ & -1059 (27) & $73(14)$ \\
\hline $\mathrm{H}(3)$ & $11804(82)$ & 3485 (18) & $-3544(22)$ & $34(10)$ \\
\hline $\mathrm{H}(4)$ & $12162(88)$ & $2700(18)$ & $-3500(22)$ & $43(11)$ \\
\hline $\mathrm{H}(5)$ & 8396 (107) & $1642(22)$ & $-825(29)$ & 70 (14) \\
\hline $\mathrm{H}(6)$ & 7406 (109) & 2069 (19) & $31(28)$ & $59(13)$ \\
\hline $\mathrm{H}(7)$ & $2254(100)$ & 3272 (19) & $2740(26)$ & $52(12)$ \\
\hline $\mathrm{H}(8)$ & $6361(108)$ & 4539 (22) & $1816(28)$ & $72(14)$ \\
\hline $\mathrm{H}(9)$ & $5274(117)$ & 3173 (19) & $531(32)$ & 79 (16) \\
\hline $\mathrm{H}(10)$ & 3309 (103) & 4455 (19) & $5161(28)$ & $69(13)$ \\
\hline $\mathrm{H}(11)$ & $1466(105)$ & $4505(21)$ & $7486(25)$ & $62(14)$ \\
\hline $\mathrm{H}(12)$ & $5675(100)$ & $5719(21)$ & $6522(26)$ & $63(13)$ \\
\hline
\end{tabular}

${ }^{\text {a }} U(\mathrm{eq})$ is defined as one third of the trace of the orthogonalized
$U_{i j}$ tensor.

for every 40 frames on all the measured reflections. Pertinent experimental details for the structure determinations are presented in Table 1 .

The structure of M.2B was solved by direct methods using SHELXS-86 [13,14] which readily established the position of the light atoms (C, N, O, B and $\mathrm{H}$ ) from difference Fourier maps. An empirical absorption correction based on symmetry equivalent reflections was applied using the SADABS [15] program. Other effects, such as absorption by glass fiber etc. were simultaneously corrected. All the hydrogen positions for the melamine and boric acid molecules were initially located in the difference Fourier maps, and for the final refinement, the hydrogen atoms were placed in the located position.
Table 3

Selected bond distances and bond angles for M.2B

\begin{tabular}{llll}
\hline Moiety & Distance $(\AA)$ & Moiety & Angle $\left(^{\circ}\right)$ \\
\hline $\mathrm{B}(1)-\mathrm{O}(1)$ & $1.370(4)$ & $\mathrm{O}(3)-\mathrm{B}(1)-\mathrm{O}(1)$ & $120.0(3)$ \\
$\mathrm{B}(1)-\mathrm{O}(2)$ & $1.372(4)$ & $\mathrm{O}(3)-\mathrm{B}(1)-\mathrm{O}(2)$ & $120.1(3)$ \\
$\mathrm{B}(1)-\mathrm{O}(3)$ & $1.349(4)$ & $\mathrm{O}(1)-\mathrm{B}(1)-\mathrm{O}(2)$ & $119.9(3)$ \\
$\mathrm{B}(2)-\mathrm{O}(4)$ & $1.352(4)$ & $\mathrm{O}(4)-\mathrm{B}(2)-\mathrm{O}(5)$ & $120.5(3)$ \\
$\mathrm{B}(2)-\mathrm{O}(5)$ & $1.356(4)$ & $\mathrm{O}(4)-\mathrm{B}(2)-\mathrm{O}(6)$ & $120.3(3)$ \\
$\mathrm{B}(2)-\mathrm{O}(6)$ & $1.373(4)$ & $\mathrm{O}(5)-\mathrm{B}(2)-\mathrm{O}(6)$ & $119.2(3)$ \\
$\mathrm{C}(1)-\mathrm{N}(4)$ & $1.339(4)$ & $\mathrm{N}(4)-\mathrm{C}(1)-\mathrm{N}(1)$ & $118.3(3)$ \\
$\mathrm{C}(1)-\mathrm{N}(1)$ & $1.339(4)$ & $\mathrm{N}(4)-\mathrm{C}(1)-\mathrm{N}(3)$ & $116.6(3)$ \\
$\mathrm{C}(1)-\mathrm{N}(3)$ & $1.353(4)$ & $\mathrm{N}(1)-\mathrm{C}(1)-\mathrm{N}(3)$ & $125.0(3)$ \\
$\mathrm{N}(1)-\mathrm{C}(2)$ & $1.344(4)$ & $\mathrm{C}(1)-\mathrm{N}(1)-\mathrm{C}(2)$ & $115.0(3)$ \\
$\mathrm{C}(2)-\mathrm{N}(5)$ & $1.338(4)$ & $\mathrm{N}(5)-\mathrm{C}(2)-\mathrm{N}(1)$ & $117.4(3)$ \\
$\mathrm{C}(2)-\mathrm{N}(2)$ & $1.348(4)$ & $\mathrm{N}(5)-\mathrm{C}(2)-\mathrm{N}(2)$ & $117.4(3)$ \\
$\mathrm{N}(2)-\mathrm{C}(3)$ & $1.338(4)$ & $\mathrm{N}(1)-\mathrm{C}(2)-\mathrm{N}(2)$ & $125.1(3)$ \\
$\mathrm{C}(3)-\mathrm{N}(3)$ & $1.339(4)$ & $\mathrm{C}(3)-\mathrm{N}(2)-\mathrm{C}(2)$ & $114.1(3)$ \\
$\mathrm{C}(3)-\mathrm{N}(6)$ & $1.351(4)$ & $\mathrm{N}(2)-\mathrm{C}(3)-\mathrm{N}(3)$ & $126.3(3)$ \\
& & $\mathrm{N}(2)-\mathrm{C}(3)-\mathrm{N}(6)$ & $117.0(3)$ \\
& & $\mathrm{N}(3)-\mathrm{C}(3)-\mathrm{N}(6)$ & $116.6(3)$ \\
& & $\mathrm{C}(3)-\mathrm{N}(3)-\mathrm{C}(1)$ & $114.1(3)$ \\
\hline
\end{tabular}

The last cycles of refinement included atomic positions for all the atoms, anisotropic thermal parameters for all the non-hydrogen atoms and isotropic thermal parameters for all the hydrogen atoms. Full-matrix-least-squares structure refinement against $\left|F^{2}\right|$ was carried out using SHELXTL-PLUS [16] package of programs. Details of the final refinements are given in Table 1. The atomic coordinates, bond distances and angles for M. $2 \mathrm{~B}$ is presented in Tables 2 and 3. The experimental powder pattern of the bulk sample is in good agreement with the simulated pattern generated from single crystal data.

FT-IR spectroscopy of M-2B on $\mathrm{KBr}$ disc indicates the presence of asymmetric and symmetric $-\mathrm{NH}_{2}$ stretching frequency at 3495 and $3415 \mathrm{~cm}^{-1}$, respectively. Sharp band around 1607 and $1249 \mathrm{~cm}^{-1}$ is due to $\mathrm{CN}$ and $\mathrm{B}-\mathrm{O}$ stretching modes. The $\mathrm{O}-\mathrm{B}-\mathrm{O}$ bending modes are observed at 803 and $652 \mathrm{~cm}^{-1}$, respectively. TGA was carried out in a nitrogen atmosphere in the $25-800{ }^{\circ} \mathrm{C}$ range. The TGA curve indicates that there is a sharp weight loss around $140{ }^{\circ} \mathrm{C}$ due the loss of three molecules of water (calc. $=21.6 \%$, obs. $=22.5 \%$ ) which is followed by a continuous weight loss till $800^{\circ} \mathrm{C}$, mainly due to the decomposition of the amine moiety. It has been observed earlier by Hagio et al. [9] using 



Fig. 1. The ORTEP plot of the asymmetric unit of M.2B. The thermal ellipsoids are given at $50 \%$ probability.

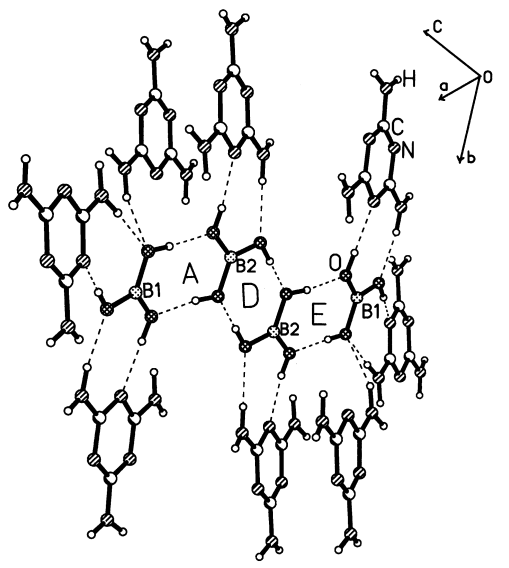

(a)

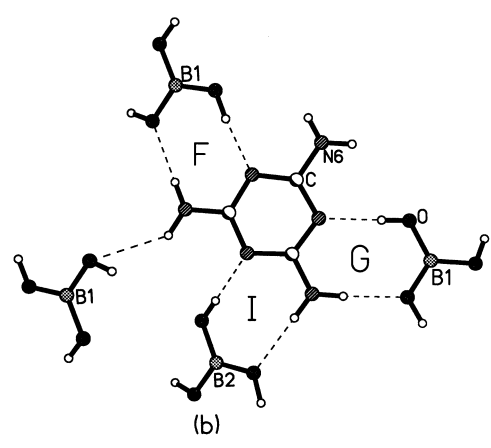

Fig. 2. (a) The finite tetrameric ribbon of boric acid and the environment of each crystallographically distinct boric acid unit. A, $\mathrm{D}$ and $\mathrm{E}$ denotes the three eight-membered $\left[\mathrm{R}_{2}^{2}(8)\right]$ ring. (b) The environment around a melamine unit has been shown, F, G and I denotes the three eight-membered $\left[R_{2}^{2}(8)\right]$ ring.
TG-mass spectrometry that (M-2B) decomposes with the evolution of $\mathrm{NH}_{3}, \mathrm{CO}_{2}$ and $\mathrm{H}_{2} \mathrm{NCN}$. The annealed product remaining at $800{ }^{\circ} \mathrm{C}$ was amorphous and weakly diffracting and yielded $\mathrm{BN}$ nanotubes on further treatment at higher temperatures [10].

\section{Results and discussion}

The asymmetric unit of $\mathrm{M} \cdot 2 \mathrm{~B}$ contains two crystallographically distinct boric acid molecules and one melamine molecule as shown in Fig. 1. The planar triangular boric acid molecules and the melamine molecule form a three-dimensional hydrogen-bonded supramolecular structure involving $\mathrm{O}-$ $\mathrm{H} \cdot \mathrm{O}, \mathrm{N}-\mathrm{H} \cdots \mathrm{O}$ and $\mathrm{O}-\mathrm{H} \cdots \mathrm{N}$ hydrogen bonds. The four $\mathrm{B}(\mathrm{OH})_{3}$ units are linked to one another to form a finite tetrameric ribbon through strong $\mathrm{O}-\mathrm{H} \cdots \mathrm{O}$ $\left(d(\mathrm{O} \cdots \mathrm{O})_{\mathrm{av}}=2.716 \AA\right)$ hydrogen bonding with the formation of three eight-membered cyclic $\left[\mathrm{R}_{2}^{2}(8)\right]$ rings [17] as shown in Fig. 2(a). In the tetramer, $\mathrm{B}(2)(\mathrm{OH})_{3}$ forms a dimer in the middle while $\mathrm{B}(1)(\mathrm{OH})_{3}$ is located at the two ends of the dimer. The $\mathrm{B}(1)(\mathrm{OH})_{3}$ unit interacts with three melamines and one boric acid, $\mathrm{B}(2)(\mathrm{OH})_{3}$. The $\mathrm{B}(2)(\mathrm{OH})_{3}$ unit, on the other hand, interacts with two boric acid molecules, $\mathrm{B}(1)(\mathrm{OH})_{3}$ and $\mathrm{B}(2)(\mathrm{OH})_{3}$, as well as one melamine molecule through $\mathrm{O}-\mathrm{H} \cdots \mathrm{O}$ and $\mathrm{O}-\mathrm{H} \cdots \mathrm{N}$ interactions, utilizing all the donor and acceptor sites. Of the six oxygens in the two boric acid units, $\mathrm{O}(6)$ attached to $\mathrm{B}(2)$ does not participate in Hydrogen bonding with the melamine molecule either as donor or an acceptor. The average $\mathrm{B}-\mathrm{O}$ bond lengths in the two distinct boric acids are 


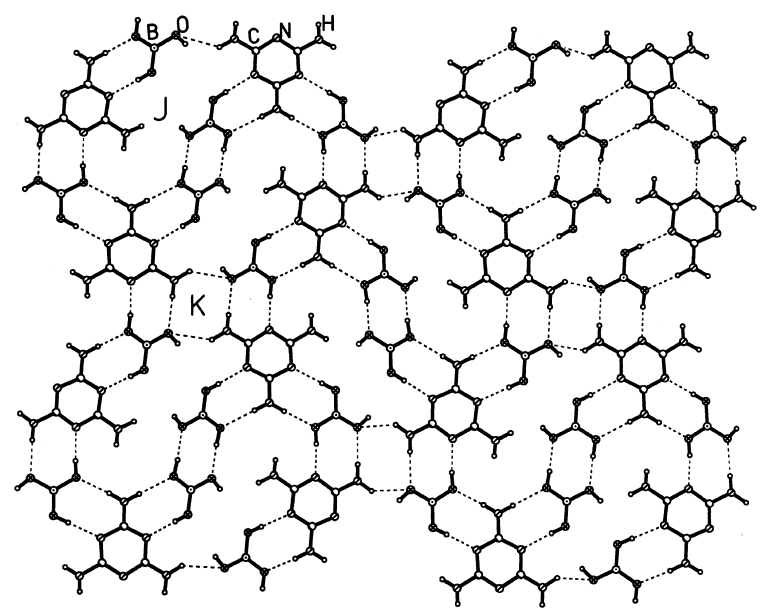

(a)

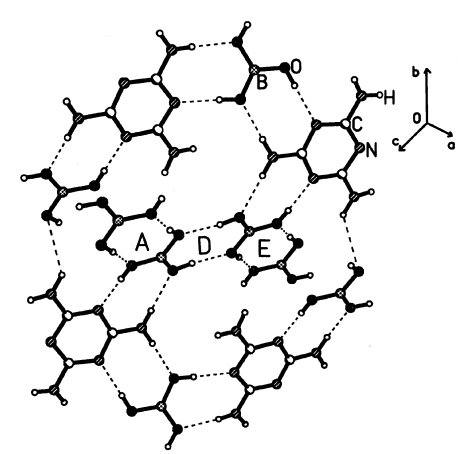

(b)

Fig. 3. (a) A projection of a section of the layer-like architecture into the $b c$-plane has been shown. $\mathrm{J}$ and $\mathrm{K}$ denotes the 22 - and eightmembered $\left[R_{6}^{7}(22)\right]$ and $\left[R_{2}^{2}(8)\right]$ ring, respectively. (b) The boric acid unit which connects the layers along the $a$-axis from top (A) and bottom (E). comparable $\left(d(\mathrm{~B}(1)-\mathrm{O})_{\mathrm{avg}}=1.363\right.$ and $\left.1.360 \AA\right)$. However, the individual $\mathrm{B}-\mathrm{O}$ distance in each boric acid moiety varies considerably depending on their participation in hydrogen bonding.

In contrast to the boric acid moieties, the melamine unit does not utilize all its donor and acceptor sites. Melamine interacts with four boric acid units through the utilization of two $\mathrm{N}$ donor sites (N4 and N5) and all the acceptor sites as shown in Fig. 2(b). Out of the four boric acid units, three form cyclic eightmembered $\left[\mathrm{R}_{2}^{2}(8)\right]$ rings [17]. It is interesting that the $\mathrm{N}(6)$ of melamine unit does not involve in hydrogen bonding. When viewed along the $a$-axis, $\mathrm{M} \cdot 2 \mathrm{~B}$ forms a layer like structure in the $b c$-plane as shown in Fig. 3(a). Within the layer, four melamine units and four boric acid units are linked alternatively to form an elliptical ring which is bisected along one of the axis by the $\mathrm{B}(2)(\mathrm{OH})_{3}$ dimer into two 22membered $\left[\mathrm{R}_{6}^{7}(22)\right]$ rings [17]. The layers are connected along the $a$-axis in $A A A A$ fashion through $\mathrm{B}(1)(\mathrm{OH})_{3}$ units as shown in Fig. 3(b) to give the three-dimensional structure. The details of the hydrogen bonding interactions in $\mathrm{M} \cdot 2 \mathrm{~B}$ are given in Table 4 .

There are many interesting features in the $\mathrm{M} \cdot 2 \mathrm{~B}$ adduct. Besides being a novel precursor for the $\mathrm{BN}$ nanotubes, it represents a rather rare hydrogen-bonded solid containing boric acid. The tetrameric ribbon in $\mathrm{M} \cdot 2 \mathrm{~B}$ is akin to a neutral ribbon of boric acid [18]. A wide variety of supramolecular adducts with melamine, where the amine uses all its donor and acceptor sites, are reported in the literature [19-21], a wellknown example being the melamine-cyanuric acid adduct with the hydrogen-bonded rosette structure

Table 4

Selected Hydrogen bond interactions in compound M.2B

\begin{tabular}{|c|c|c|c|c|}
\hline $\mathrm{D}-\mathrm{H} \cdots \mathrm{A}$ & $\mathrm{D}-\mathrm{H}$ & $\mathrm{H} \cdots \mathrm{A}$ & $\mathrm{D} \cdots \mathrm{A}$ & $\mathrm{D}-\mathrm{H} \cdots \mathrm{A}$ \\
\hline $\mathrm{N}(4)-\mathrm{H}(1) \cdots \mathrm{O}(2)$ & $0.93(4)$ & $2.05(4)$ & $2.977(4)$ & $175(3)$ \\
\hline $\mathrm{N}(4)-\mathrm{H}(2) \cdots \mathrm{O}(2)$ & $0.95(4)$ & $2.57(4)$ & $3.308(5)$ & $135(3)$ \\
\hline $\mathrm{N}(5)-\mathrm{H}(3) \cdots \mathrm{O}(4)$ & $0.90(3)$ & $2.07(3)$ & $2.964(5)$ & $180(3)$ \\
\hline $\mathrm{N}(5)-\mathrm{H}(4) \cdots \mathrm{O}(3)$ & $0.92(4)$ & $1.94(4)$ & $2.853(4)$ & $172(3)$ \\
\hline $\mathrm{O}(1)-\mathrm{H}(7) \cdots \mathrm{N}(2)$ & $0.86(4)$ & $1.92(4)$ & $2.781(4)$ & $180(4)$ \\
\hline $\mathrm{O}(2)-\mathrm{H}(8) \cdots \mathrm{O}(5)$ & $0.89(4)$ & $1.79(4)$ & $2.671(4)$ & $174(4)$ \\
\hline $\mathrm{O}(3)-\mathrm{H}(9) \cdots \mathrm{N}(3)$ & $0.90(4)$ & $1.85(4)$ & $2.747(4)$ & $174(4)$ \\
\hline $\mathrm{O}(4)-\mathrm{H}(10) \cdots \mathrm{O}(6)$ & $0.92(4)$ & $1.84(4)$ & $2.759(4)$ & $174(3)$ \\
\hline $\mathrm{O}(5)-\mathrm{H}(11) \cdots \mathrm{N}(1)$ & $0.84(4)$ & $1.87(4)$ & $2.702(4)$ & $174(4)$ \\
\hline $\mathrm{O}(6)-\mathrm{H}(12) \cdots \mathrm{O}(1)$ & $0.88(4)$ & $1.84(4)$ & $2.718(4)$ & $172(4)$ \\
\hline
\end{tabular}


[21]. Surprisingly in the present case, one of the $\mathrm{NH}_{2}$ groups does not participate in hydrogen bonding. There is no proton transfer between the amine and boric acid.

In the hydrogen bonded structures formed by boric acid or by the monomeric borate species reported in the literature, infinite ribbon of $\mathrm{B}(\mathrm{OH})_{3}$ and $\mathrm{BO}(\mathrm{OH})_{2}^{-}$ [6], a rosette-like structure of $\mathrm{B}(\mathrm{OH})_{3}-\mathrm{CO}_{3}^{2-}$-urea linkages [7] and head-to-head dimer of $\mathrm{B}(\mathrm{OH})_{3}$ [8] are known to occur. Thus, the hydrogen bonded structure in $\mathrm{M} \cdot 2 \mathrm{~B}$ is quite different, having a finite tetrameric ribbon of $\mathrm{B}(\mathrm{OH})_{3}$.

\section{Acknowledgment}

One of the authors (AR) thanks University of North Bengal, Darjeeling for a leave of absence.

\section{References}

[1] J.B. Farmer, Adv. Inorg. Chem. Radiochem. 25 (1982) 187.

[2] K.M. Turdybecov, Yu.T. Struchkov, V.M. Akimov, V.G. Skvortsov, O.V. Petrova, Sh.V. Sadetinov, Zh. Neorg. Chim. 37 (1992) 1250.

[3] N.V. Loboda, M.Yu. Antipin, V.M. Akimov, Yu.T. Struchkov, V.G. Skvortsov, O.V. Petrova, Sh.V. Sadetdinov, Zh. Neorg. Chim. 39 (1994) 547.
[4] C.C. Freyhardt, M. Wiebcke, J. Felsche, G. Engelhardt, J. Inclusion Phenom. Macrocycl. Chem. 18 (1994) 161.

[5] Q. Li, T.C.W. Mak, Supramol. Chem. 8 (1997) 147.

[6] C.C. Freyhardt, M. Weibcke, J. Chem. Soc., Chem. Commun. (1994) 1675.

[7] Q. Li, F. Xue, T.C.W. Mak, Inorg. Chem. 38 (1999) 4142.

[8] S.J. Andrews, D.A. Robb, A.J. Welch, Acta Crystallogr. C39 (1983) 880.

[9] T. Hagio, K. Kobayashi, T. Sato, J. Ceram. Soc. Jpn 102 (1994) 1051.

[10] R. Ma, Y. Bando, T. Sato, Chem. Phys. Lett. 337 (2001) 61.

[11] R. Ma, Y. Bando, T. Sato, K. Kurashima, Chem. Mater. (2001).

[12] Siemens Users Manual, Siemens Analytical X-ray Instruments, Madison, WI, 1995.

[13] G.M. Sheldrick, SHELXS-86 Program for Crystal Structure Determination, University of Göttingen, Germany, 1986.

[14] G.M. Sheldrick, Acta Crystallogr. A35 (1990) 467.

[15] G.M. Sheldrick, SADABS Siemens Area Detector Absorption Correction Program, University of Göttingen, Germany, 1994.

[16] G.M. Sheldrick, SHELXTL-PLUS Program for Crystal Structure Solution and Refinement, University of Göttingen, Germany, 1993.

[17] M.C. Etter, J.C. MacDonald, Acta Crystallogr. B46 (1990) 256.

[18] A.F. Wells, Structural Inorganic Chemistry, 5th ed., Clarendon Press, Oxford, 1984, p. 1067.

[19] J.A. Zerkowski, C.T. Seto, D.A. Wierda, G.M. Whitesides, J. Am. Chem. Soc. 112 (1990) 9025.

[20] J.A. Zerkowski, J.C. MacDonald, G.M. Whitesides, Chem. Mater. 6 (1994) 1250.

[21] A. Ranganathan, V.R. Pedireddi, C.N.R. Rao, J. Am. Chem. Soc. 121 (1999) 1752 